\title{
The slow-changing face of leadership in ballet: an interdisciplinary approach to analysing women's roles
}

\author{
Lisa DeFrank-Cole \\ Associate Professor and Director of Leadership Studies, West Virginia University, Morgantown, WV, USA
}

Renee K. Nicholson

Assistant Professor of Multidisciplinary Studies, West Virginia University, Morgantown, WV, USA

The parallels between the arts and leadership have been underexplored, especially in the context of classical ballet. An interdisciplinary exploration of ballet and leadership by a leadership scholar and a classically trained ballet dancer enable a thorough and thoughtful look at the intersections of these worlds. This will bring a fresh perspective to ballet's unique culture, one often stuck in nineteenth-century contexts based on outmoded gender roles.

Women dominate the art form yet few rise to prominent leadership roles. Data reveal unequal opportunities for women in areas such as choreography. Moreover, choreographers embody a different kind of artistic leadership, crafting the way audiences view the dancers in the troupe. Men most often craft this view of women with the works they choose to present. A recent accounting of choreographic works by major American ballet companies showed that women choreographed only 25 of the 290 ballets performed in 2012. Thus, on stage, men largely manipulate the image of women in ballet. If 'ballet is woman,' according to the late choreographer George Balanchine, why are there still so few at the top?

The example pulled for a new outlook breaks with outmoded representation. Bold, confident, and embodying a very different paradigm, Misty Copeland (American Ballet Theatre's principal dancer) presents a different face of the ballet dancer/leader. This paper gives a brief history of the introduction of ballet to the United States, highlights gender norms in the context of leadership and offers a different perspective on women's roles as leaders in dance.

Keywords: women, leadership, ballet

\section{INTRODUCTION}

The relationship between the arts and leadership has been underexplored, especially in the context of classical ballet. Women dominate the art form yet few rise to prominent leadership roles. If 'ballet is woman,' according to the late choreographer George Balanchine, why are there still so few in top leadership positions?

Classical ballet may not always be the first place scholars of leadership think to look for leadership traits, but it presents an opportunity to explore a specific arts culture rooted in a deep history with compelling issues to those interested in women and leadership. What women dancers learn as a part of their art can be viewed in leadership contexts, and with more exposure to leadership scholars, researchers, educators, and development practitioners, valuable knowledge and experiences can be shared. An interdisciplinary 
exploration of ballet and leadership by a leadership scholar and a classically trained ballet dancer enable a thorough and thoughtful look at the intersections of these worlds. This will bring a fresh perspective to ballet's unique culture; one often stuck in nineteenth-century contexts based on outmoded gender roles. The examples pulled for a new outlook break with outmoded representation, especially that constructed by George Balanchine, who is credited with being one of the most influential founders of serious American ballet. Bold, confident, and embodying a very different paradigm, Misty Copeland (American Ballet Theatre's principal dancer) presents a different face of the ballet dancer/leader. As artistic director of the Miami City Ballet, Lourdes Lopez, a Cuban-American, also provides a unique viewpoint on ballet. However, most women in ballet still struggle to find leadership opportunities within ballet companies.

\section{ORIGINS OF BALLET}

When Catherine de Medici married French heir to the crown, Henri II, in 1547, she brought her Italian balletti master with her to court, which became ballet de cour and the beginnings of what would become known as ballet. According to ballet historian and former dancer Jennifer Homans (2010, p. xxiv), 'at its origins, [ballet] was an aristocratic etiquette and political event as much as it was an art'. The remnants of this alliance of the French and Italian aristocracy and culture include ballet's continued hierarchical structure. In 1661 Louis XIV established a royal dance academy, in part to enforce discipline at court. Dancers at this time were mostly men, and included both the nobles and the king's dancers and dancing masters, who established a guild, not unlike today's union, the American Guild of Musical Artists (AGMA). These early guilds played an important role in the way ballet dancing progressed. 'The guild controlled access to the profession (and provided benefits to its members) and the dancers generally had to pass through it to secure the credentials necessary for good employ' (Homans 2010, p. 16).

The guilds are important in another aspect, which is moving ballet from the European courts and into the theater. But the rules of the court remained present in the transition to becoming a theater art, and today, the hierarchy within a ballet company remains one of those imprints back to the Renaissance. It is interesting to contemplate whether or not this very hierarchical structure is one of the reasons that women do not play a large role in leadership positions today.

Today, the corps de ballet, or large body of dancers, consists mostly of women, and has often been compared to the backbone or spine in the body, as the framework and support for a large portion of a company's repertoire. 'The corps is an integral part of a dance company. They're the base that helps weave the tale' (Copeland 2014, p. 154). Working together as a cohesive whole, the corps comprises a living backdrop to most classical ballets. As this support, the members of the corps have strenuous work schedules and demanding performance responsibilities. Although now a principal dancer, Misty Copeland described her experience as 'one of the cattle in the corps. It was intensely competitive' (ibid., p. 155). As those few lucky enough to move up the hierarchy, soloists and principals often dance fewer times than the members of the corps.

As dance historian Jennifer Homans asserts, today's ballet retains the imprint of the aristocracy, even as it moves from court to the theater. 'Ballet, after all, was a perfect artifact of seventeenth century French aristocratic culture: an amalgam of the rules and regulations of court life' (Homans 2010, p. 48). Instead of courtiers winning favor with a king, dancers work to impress the artistic director, who runs the artistic life of the 
company, from the selection of dancers to the selection of repertoire. From the time that ballet moved from the court to the theater, it still remained under the control of a single, male figure, who set wages, assigned roles, and could fire the dancers, who in the early migration to the theater, worked without a contract. 'Corps de ballet members tended to suffer in silence, rarely protesting a system that fed off their youth and labor' (Kelly 2012, p. 60). Misty Copeland compares moving from the studio company, a training ground for dancers almost ready to move from student dancer to the corps de ballet, as being 'like going from the minor leagues to the main team's second string' (Copeland 2014, p. 154). This tradition persisted in the establishment of ballet companies in the United States, most notably from the influence of George Balanchine.

\section{BALANCHINE'S INFLUENCE ON BALLET IN THE UNITED STATES}

George Balanchine, a pre-eminent twentieth-century choreographer and co-founder of the New York City Ballet (NYCB) and the School of American Ballet (SAB), both of which had immense influence on the study and performance of ballet in America, began his studies of classical dance in 1914 at the Imperial Ballet of Russia. The traditions of the Russian ballet were built upon the French and Italian schools from the dance masters it imported from these countries. French choreographer Marius Petipa and Italian dancing master Enrico Cecchetti came to the Russian court to build a great ballet company, and through their efforts set ballet on a distinctly Russian pathway under a strictly formal and courtly system.

When the revolution came, Balanchine, who had just turned thirteen, watched the majestic and seemingly eternal Imperial world of his childhood collapse. And if he subsequently turned on its conventions and went the way of radical Russian modernism and progressive art [in his choreography], he also pressed the beauty and elegance of the court and its dying aristocratic world deep into his memory. (Homans 2010, p. 505)

So while Balanchine broke with the traditions of classical ballet in his choreography, most notably in stripping ballets of the need to tell a story, as well as paring down many ballet sets and costumes, presenting many master works in practice clothes (his 'leotard' ballets), he also sustained traditions of the past. His school was codified and leveled, and his company followed the hierarchical structure of corps, soloists, and principal dancers.

The school and the company were run like a miniature Imperial court, with Balanchine as Tsar. These were unabashedly hierarchical institutions in which authority went unchallenged, but they were also rigorously meritocratic. Dancers were trained and ranked as an aristocracy of skill, and they learned the manners and military-style discipline traditionally demanded of the tsar's entourage - and of his dancers. (ibid., p. 507)

This militaristic structure of leadership is quite different from the collaborative structures that women are said to prefer (Helgesen 1995, p. 46).

Balanchine's influence is a part of every ballet school and company in the US today. His School of American Ballet and New York City Ballet served as the training ground for many of the dancers who would go on to found and run schools and companies elsewhere in America. So in a place founded on principles very different than the aristocracy, an artistic tradition steeped in aristocratic tradition bloomed. Watching ballets today, one can see the imprint; the corps still serves as a living backdrop to 
soloists and principal dancers, and that corps is made up mostly of women. The movements of the corps are highly synchronized and precise, with the goal of moving seamlessly as one, where women do not show individual talent - or leadership - but one where they are blended together and obedient to the master. At the same time as he was shaping the organization, he was also shaping the individual.

Balanchine shaped the look of the modern, Western ballet dancer. 'Balanchine made the ballerina symbolic of his new direction in ballet, even redesigning her image according to his own image of what the ideal female dancer should look like: tall, with long legs, highly arched and flexible feet, narrow hips, long arms and a small head' (Kelly 2012, p. 131). Even as Misty Copeland rose through the ranks of ballet, she felt the pressure of appearance, not only in body type but also as an African American woman. 'A time would come when I would be told that I was too heavy, that my breasts were too big, that my skin was too dark' (Copeland 2014, p. 109). Copeland, despite receiving this criticism, is barely over a hundred pounds in weight and a size 0. However, Balanchine's taste still tends to be the rule. As the founder of one of the first and what would become most prominent American dance organizations, Balanchine could dictate these rules according to his tastes. While dancers belonged to a union, they were barely tolerated by Balanchine, who demanded absolute control of his dancers and his company, which caused many to look upon NYCB as a kind of cultish organization. Among his critics were also some of his dancers, most notably the ballerina Gelsey Kirkland, who ultimately left NYCB to dance with American Ballet Theatre (ABT), but whose scars from her years dancing for Balanchine were evident in her memoir, Dancing on my Grave (Kirkland and Lawrence 1986, pp. 53-117). While other accounts of Balanchine treat him more charitably than Kirkland does, his authority goes largely unchallenged:

While he was ballet-master-in-chief of the New York City Ballet, Balanchine intensified the tyranny of artistic director and sparked the epidemic of eating disorders arising from his preference for lean and leggy ballerinas. Balanchine claimed to idolize ballerinas and publically called them his muse. But behind the scenes, he subtly and systematically degraded them, denying them sex (unless it was with him) and sustenance, both in the form of food and domestic fulfillment. (Kelly 2012, p. 129-130)

Balanchine's extraordinary talents as a musically gifted and visionary choreographer are only one part of his enduring legacy; his unattainable feminine ideal plays an important role in the culture of ballet in the US and beyond.

\section{BALANCHINE'S LEADERSHIP STYLE}

As a leader, it is clear that Balanchine was hierarchical and authoritative, enjoying his position at the top and making all the decisions. The hierarchical style of leadership is often linked with men (Carli and Eagly 2001; Eagly and Johannesen-Schmidt 2001). He displayed his power - both positional and personal. Based on French and Raven's (1959 [1968]) study of power, the Five Bases of Power include Referent, Expert, Legitimate, Reward, and Coercive (Cartwright and Zander 1968). Balanchine demonstrated power specifically through his role as artistic director, where he had legitimate power from his formal position. He also held reward power by being able to assign specific and desirable roles to dancers in his ballet. Lastly, he claimed coercive power through his ability to punish dancers by giving them lesser roles or firing those who did not submit to his authority. 
Balanchine also demonstrated the Leader-Member Exchange Theory in his approach. 'Within an organizational work unit, subordinates become a part of the in-group or the out-group based on how well they worked with the leader and how well the leader works with them. Personality and other personal characteristics are related to this process' (Northouse 2013, p. 163). Looking to the relationship Balanchine had with his dancers, Gelsey Kirkland and Diedre Kelly describe a man who became enchanted with those he loved and dismissed those whom he perceived betrayed him. Those dancers with whom he had close relationships benefited in their dancing careers (James 2007, p. 21). He was married four times in his life, each time to one of his dancers (West 2010). Presumably the marriage contract provided the ultimate in-group relationship.

\section{BALLET IS WOMEN - EXCEPT WHEN IT COMES TO LEADERSHIP}

George Balanchine famously proclaimed, 'Ballet is woman.' However, in terms of its leadership, it is not. Notably, Balanchine chose Peter Martins as his successor to run both NYCB and associated training facility, SAB. 'Danish born, he is the dominant player in American ballet' (Rockwell 2006). However, his success in this role has been widely debated. Pre-eminent dance historian Jennifer Homans described his tenure at NYCB as 'a lifeless orthodoxy' (Rockwell 2006). Furthermore, Homans, director of the Center for Ballet and Arts at New York University, maintains that ' $[\mathrm{t}]$ he culture of ballet is one of hierarchy and obedience, that makes it difficult for women to excel as leaders' (Basco 2015). Mr Martins, in interview, describes his own style as: 'I watch everything and everyone; I don't miss a trick' (Sulcas 2013). Martins, like his predecessor, seems to have adopted a similar style of hierarchy and a penchant for hiring men into the most plum assignments (ibid.).

While there is not a great deal of data available, what there is reveals unequal opportunities for women in areas beyond artistic direction, such as choreography. The sequence of steps for staged dance, or choreography, is rarely an activity ascribed to a woman. Furthermore, choreographers, who are often former dancers, embody a different kind of artistic leadership, crafting the way audiences view the dancers in the troupe. This view is most often crafted by men, even though more dancers are women than men. A recent accounting of choreographic works by major American ballet companies showed that women choreographed only 25 of 290 ballets performed in 2012. Thus, on stage, the image of women in ballet is largely manipulated by men. Directors are not choosing women choreographers regularly as a part of their programming.

Joseph Copley, a coordinator in the industry, compiled (and researchers verified) the number of works choreographed by women in the 2012 performance season, shown in Table 1. While the chart is a simple accounting, it is telling. Choreographic works by women are far less represented across the United States than those developed by men. 'In classical dance, female choreographers are rare indeed,' states Luke Jennings (2013). While choreography is only one measure of influence within a performance (compared with being the artistic director, for example), it is beneficial to better understand gender roles in society as they are applied to leadership within a ballet company or other organization.

Supporting Copley's work, Sharon Basco noted in her 2015 article on women in ballet that 'the choreography is, with perhaps one exception per season, by men.' Furthermore, Lynn Garafola, a noted dance writer and scholar, and founder of the Columbia University Seminar Studies in Dance notes that the precious few pieces 
78 Leadership and the Humanities, Vol. 4 No. 2

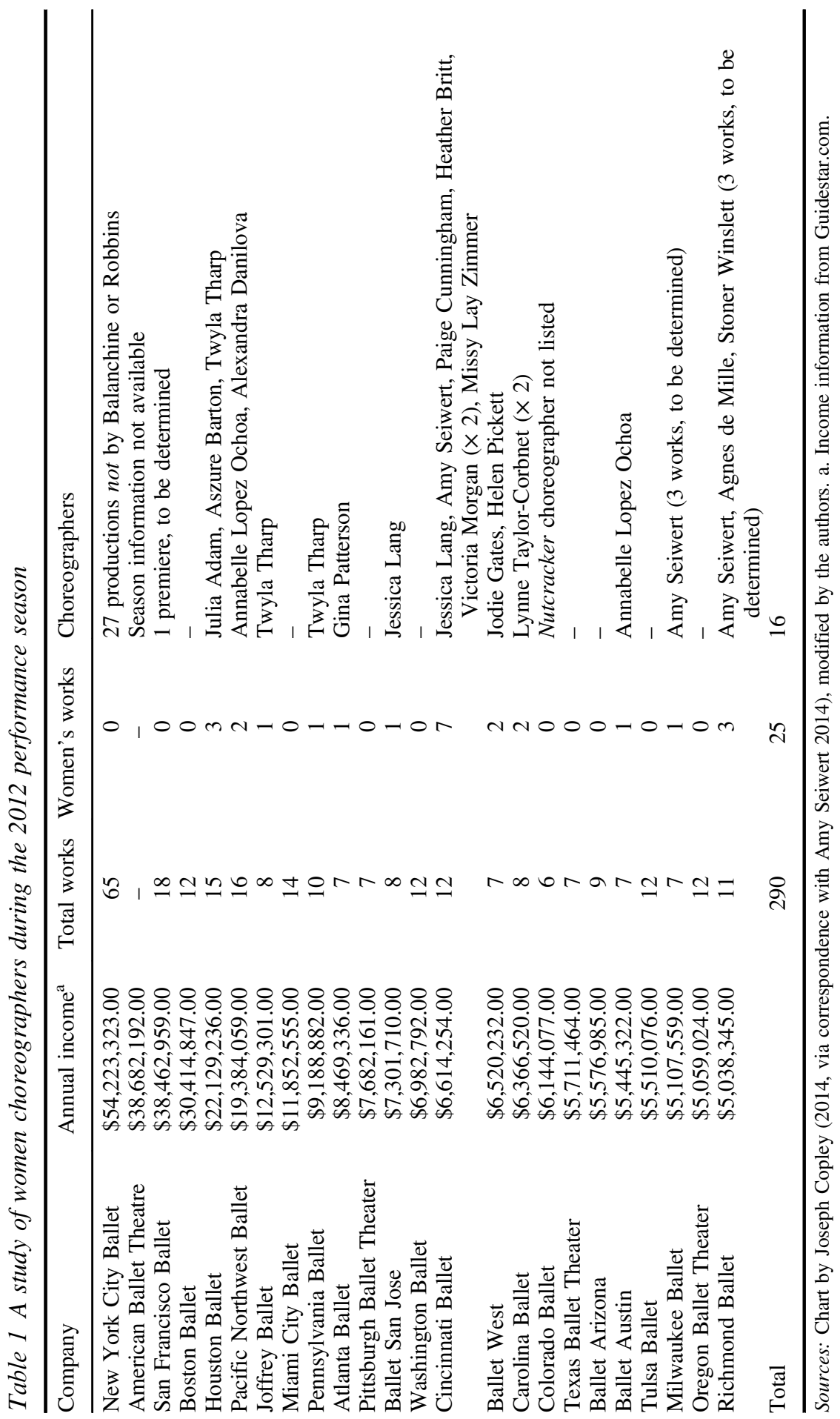


created by women for the ballet 'are by well- established choreographers, not neophytes' (Basco 2015). To present the work of a choreographer like Twyla Tharp, Garafola maintains, is not seen as taking a risk. However, the opportunities for new male choreographers is much different. Alexi Ratmansky, Christopher Wheeldon, Justin Peck and other men have forged careers in the post-Balanchine era. Part of this may be the male roles within the ballet companies themselves, where ' $[\mathrm{t}]$ heir workload is lighter, the competition is nowhere as intense as it is among those ethereal women in tutus. So the men in ballet have time to develop their creativity, to experiment with choreography, to get out into the non-ballet world and develop other skills' (Basco 2015).

Among more established directors, Peter Martins at NYCB can simply insert himself into the role of choreographer, without having to worry about his ability or not. Many critics feel Martins has produced too many works for NYCB, citing that 'his ballets are not widely picked up by other companies, and he has turned in his share of bland and formulaic exercises' (Rockwell 2006).

\section{THE CHANGING FACE OF LEADERSHIP IN BALLET}

\subsection{Case study 1: Misty Copeland}

One ballerina who has become a leader in a different way than as an artistic director or a choreographer hails from the ranks of ABT. Misty Copeland attended ABT's summer intensives, worked in the studio company, and rose from the corps to soloist and most recently to principal dancer. She is the first African American dancer to achieve this rank. While Copeland continues her ascent within the structure of ABT, she expresses leadership in other ways.

As a child, Copeland came to dance through the Boys and Girls Clubs (the US-wide organization dedicated to improving educational and life opportunities for young people and especially those in need), and her teacher there, Cindy Bradley, recognized her talent and gave Copeland a scholarship to her studio to train. In an effort to help more children, especially those from lower economic neighborhoods and children from a more diverse ethnic background, Copeland has become the spokesperson and 'face' for ABT's Project Plié, where ABT-trained teachers give movement classes at Boys and Girls Clubs to assess for potential study. While Copeland started ballet training late, at age thirteen, her efforts on behalf of and in support of Project Plié will help other children be exposed to the art form at an age more typical for training. Of her own late start, she writes, '[m]ost ballerinas start to dance when they are sipping juice boxes at school. I was thirteen years old. Self doubt haunted me' (Copeland 2014, p. 38).

The amazing journey from living in a motel with her mom and siblings to becoming a rising star on the ballet stage, though unlikely, also shows how training and performing classical ballet is anything but easy. 'As a professional, you have to endure a tremendous amount of criticism and judgment leading up to a performance. You can barely take a step in a rehearsal before the dance mistress will clap, stop you, and give you a critique' (ibid., p. 25). The judgment doesn't stop in the studio, but continues on the stage with professional reviewers, audience members, and the company's artistic staff. The young dancers get a taste of this auditioning for summer intensive programs. Most ballet companies, including ABT, offer these programs by competitive audition, looking for the best talent to invite to their pre-professional training programs in hopes of shaping the best into the next generation of performers. 'Summer intensive programs are also a critical rung on the ladder for young dancers aspiring to one day be a part of ABT, the 
Joffrey, or any other of the prestigious ballet companies in the United States,' Copeland writes (ibid., p. 104). While she was awarded scholarships to many of the best schools, such as the San Francisco Ballet and ABT, she was also denied entry into SAB, the official school of NYCB. This denial is echoed, not word for word but in spirit, in the advertisement Copeland shot for the athletic wear brand Under Armour.

Regal, athletic, self-assured, Misty Copeland balances sur la pointe in the Under Armor (2014) commercial, as a sign of female empowerment. In a child's voice, a letter is read, starting 'Dear Applicant,' and continues on, listing reasons such as age and body type as to why the dancer was not accepted into a ballet school. This harkens back to the grueling auditions each aspiring dancer faces. Copeland details the process:

The tryouts usually took place over the course of a single month, each school required its own particular uniform - black leotard, pink tights, no distracting colors! You'd show up at your allotted time, pay a small fee, and be given a number to wear over your chest. Then you and fifty or sixty other dancers would go through the moves of a typical ballet class, at the barre, in the center, while a school representative stood to the side or behind a table, watching closely. (Ibid., p. 135, emphasis in original)

From this format, dance students are selected and notified via mail or email of their acceptance, wait-listed status, or rejection from the schools. It is not unusual to audition for many schools in a single month or six-week period.

In contrast to the rejection notice being read, in the Under Armour 'I Will What I Want' commercial, the poised and assured Copeland begins to dance, both with athletic prowess and graceful lines. She wears not the tutu and tiara associated with the typical ballerina, but tight-fitting athletic gear, which shows the sculpted musculature of her legs, arms, and torso. Her look is one of determination and focus. This commercial, which blends ballet, athletics, and popular culture, is an early sign of the slow changes occurring within the ballet world. Few if any ballet dancers are household names, while Copeland has been featured in this and a commercial by Dr Pepper, in Time as one of the most influential people of 2014, and on tour with the musical artist, Prince. Because of these non-traditional appearances for a ballerina, Copeland is becoming the 'face' of the art form more than any other dancer. Because her body type goes against the typical form, and because of her skin color, she represents a shift both within and outside the culture of ballet. Forthright about the confines of the stereotypical ballerina, Copeland is well aware of the typecast. 'You can have everything that is required physically for ballet,' she writes, 'the capacity to execute each step perfectly, but if your head is not proportional to the rest of your body, or your eyes are too close together, it could mean the difference between an acceptance and rejection by a premier ballet company' (ibid., p. 108). This underscores how remarkable Copeland's ascent has been, and because it extends past the confines of ballet culture into a larger popular culture, it is all the more extraordinary. 'The spotlight has often been focused on me because I was a late bloomer who turned out to be a prodigy, and perhaps more than that, because I am a black woman excelling in a white world' (ibid., p. 143).

During her ascent at ABT, Copeland had to contend with the inevitable injuries that dancers endure. This process, although common, is also difficult to manage for dancers. 'An injury can be as psychologically painful as it is physically painful. One day you are on the stage and you're the star. The next day you're out with an injury and someone else is on the stage, dancing your part' (ibid., p. 160). Despite injuries, after six years in the corps de ballet, starting at age nineteen, Copeland was promoted by ABT artistic director Kevin McKenzie to soloist. In June 2015, Copeland was again promoted, this time to principal dancer. The process was fraught with difficulties, 
including competing with her friends for roles. As a soloist, she had performed many principal roles, including the new choreography of The Firebird, by ABT artist-inresidence Alexi Ratmansky, and as the double role of Odette/Odile in Swan Lake. Writing in The Wall Street Journal about Copeland's New York debut in Swan Lake, critic Pia Catton (2015) reflects on the difficulty of this particular role: "The role of Odette/Odile in "Swan Lake" is one of the most significant in the classical ballet repertory, requiring a range of emotions - from crushing sorrow to steely seduction - and virtuoso technique.' Of Copeland's performance specifically Catton writes, ' $[\mathrm{h}] \mathrm{er}$ performance as Odette, the White Swan, was notable for its varied use of timing and quick, bird-like movements' (ibid.).

Misty Copeland has also represented ABT in the Princess Grace Foundation awards and other prestigious competitions, showing her director's faith in her and her abilities, and also giving her leadership opportunities. Copeland was also recognized as an outstanding alum of the Boys and Girls Clubs of America. In reflecting on this honor, Copeland (2014, p. 232) writes, '[a]s a ballerina, we don't often feel the benefits of a lifetime of hard work and determination put into our craft.'

Certainly, Misty Copeland stands as a very different kind of ballet dancer than the one that George Balanchine envisioned. However, she can also be seen as ushering in new roles for female dancers, not just on stage, but in other contexts. She is active in social media, and her popularity tends to lead to sold-out performances when she is featured in the work. While many ballet dancers silently perform only on the stage, Copeland reaches out to others, through her writing, social media, or her advocacy of dance through Project Plié. She doesn't exist solely as the image of the art form, but engages others often those in groups not currently interested in ballet - by welcoming them into her process of becoming a ballet dancer.

\subsection{Case study 2: Lourdes Lopez}

Lourdes Lopez is a trailblazer who is opening up roles for women to serve as leaders of ballet companies. It is well known that women are underrepresented in business and government but the arts have not been investigated in the same ways. Women hold fewer than 5 percent of Fortune 500 CEO positions (Catalyst 2016) and make up less than 20 percent of the US Congress (Women in the US Congress 2016). However, what is discussed less often is the role of women leaders in the arts. Specifically, in ballet, where so many women dominate the stage, very few serve as leaders in the organizations that produce the performances.

The very attributes that are cited as good leadership qualities including being competitive, self-confident, and ambitious (Eagly and Karau 2002, p. 574) can be found in women who dance classical ballet. Yet women rarely become the creative leaders of companies (Jennings 2013). If serving in those roles, what could be expected from these women leaders?

There are definite benefits in having women serve as leaders in organizations, including nonprofits, such as ballet theaters. For the purposes of this article, three main benefits of having women play stronger leadership roles are noted: enhanced creativity, stronger connections/inclusivity, and possibly improved financial results. Also in this line of leaders is Lourdes Lopez, artistic director of Miami City Ballet.

While modern dance has enjoyed female leaders in the role of artistic director, from the iconic and influential Martha Graham, who created Martha Graham Dance Company, to Judith Jamison, assuming artistic director of the Alvin Ailey American Dance 
Theatre, ballet companies have fewer who rise to the rank of artistic director. Former Balanchine-trained dancer and NYCB principal Lourdes Lopez, however, assumed the artistic director post at Miami City Ballet in 2013. 'Especially notable for a Latina, Lopez has joined a tiny club of female company directors' (Guillermo 2013).

Lopez assumed the helm of the Miami company during fraught times. Founder and artistic director Edward Villella, a former Balanchine star, left Miami City Ballet abruptly amid frequent troubles with the company's board. His departure was described as 'stunning and distressing the dancers, many whom had danced for him for their entire careers. Mr. Villella helped establish the company and was its patriarch' (Wakin 2012). At the time that the board chose Lopez to succeed him, she had been running a small, experimental company, and had experience as a culture reporter for WNBC in New York City, as an administrator for the training center Ballet Academy East, and as Executive Director for the George Balanchine Foundation. Though she had a solid background in the arts, what would prepare her to take on a position with a company in crisis? Was this an opportunity to chip away at the glass ceiling in the ballet world?

Rather than breaking the glass ceiling, women who are given leadership roles are sometimes taking positions on 'the glass cliff.' Haslam and Ryan coined this term in the early 2000s referring to leadership positions that are perilous for women. The glass cliff is 'an allusion to the fact that their leadership positions are relatively risky or precarious since they are more likely to involve management of organizational units that are in crisis' (Haslam and Ryan 2008, p. 531). Women who want leadership roles sometimes have no choice but to take posts that are somewhat less desirable due to significant issues, such as financial troubles. However, they may be blamed for poor performance when the damage was done before they actually took on the mantle of leadership. This leads people to think that poor performance is linked directly to a woman's bad leadership rather than taking into account the situation and context (ibid.). This, however, does not seem to be an issue for Lopez.

Women who take on risky positions may also have been sought out for their stereotypical 'risk averse' behavior. Maxfield et al. (2010, p. 595) build on the work of Haslam and Ryan by stating 'in times of positive performance, organizations "think manager, think men." Yet in times of high risk, organizations "think crisis, think women" and often put women into top leadership, relying on their relational skills to turn organizations around.' According to Maxfield et al. (ibid.), women are not always risk-averse it depends on the context. If the context is health and safety, women are more risk-averse but when it comes to other areas, the results are more nuanced (ibid.). Whether she has been on a 'glass cliff' or selected for her steady hand, taking on a company in crisis was a risky venture for Lopez, one that seems to be paying dividends.

Soon after her installation, dancers from the corps through the principal ranks saw her unique leadership style as an asset to the company. In 2013, dancer Adriana Pierce praised Lopez's 'positive vibe' and credited Lopez with bringing a much more diverse repertoire as well as encouraging choreography projects from dancers (Guillermo 2013). A popular principal dancer, Jennifer Kronenberg, also praised Lopez for maintaining an open-door policy, which she says is a luxury in ballet companies. Furst and Reeves (2008, p. 379) state that '(1)eaders who communicate openly, demonstrate integrity and trust, and encourage participation should outperform those with a more traditional, command and control style of leadership.' As evidenced by Pierce's and Kronenberg's comments, it is clear that Lopez's leadership style is beneficial based on research on the topic. She is listening to her dancers, taking their input and having 
open lines of communication. In a short few years, Lopez's approach is producing results.

When asked about her success at Miami City Ballet and as a female artistic director, Lopez 'insists success in this spotlight hinges not so much on gender issues as meeting challenges as a "fully realized human being" (Guillermo 2013). However, there may be evidence that Lourdes Lopez has taken challenges and risks because of her sensitivity to gender.

Current Miami City Ballet principal dancer Simone Messmer danced with both ABT and San Francisco Ballet without realizing her full potential as a dance artist. In 2016, Messmer's performances with Miami City Ballet during their New York tour were highly praised in critical circles, especially The New York Times. Messmer's ascent has occurred under Lourdes Lopez's tenure as artistic director, which, at the time of the New York tour would be four years into that role. Messmer had approached Lopez about joining the troupe, and Lopez's consideration cuts right to the gender issues often experienced in ballet. In speaking to teachers and dancers who had worked with Messmer, '[t]hey all said she was really talented, she's a workaholic, she's very focused and present, she delivers on stage, but she has a strong personality and asks a lot of questions and wants to know the answers ... There was a part of me that made me wonder: if we were talking about a male dancer, would you have the same reaction?' (Kourlas 2015). In many ways, this hints at Lopez's willingness to take risks on female dancers that male colleagues would not. Talking about Lopez's leadership of the company during the New York run, Messmer says of her artistic director, '[s] he's a different kind of director than I've had in the past ... she's supportive but tough. She really knows who she has in front of her. And she's a strong woman' (Harss 2016). Messmer's performance in the Balanchine classic Serenade was mentioned by New York Times critic Alastair Macaulay in particular, who said Messmer was 'reaching her high summer' (Macaulay 2016b). Furthermore, he noted that the troupe brought an impressive list of choreography, including works by Twyla Tharp. In a separate review, the critic wrote that 'the season firmly placed this troupe at the forefront of all those dancing choreography by George Balanchine today' (Macaulay 2016c).

In addition to presenting Balanchine's works, Lopez has taken risks to adapt it more to the company's hometown. Presenting Balanchine's Midsummer Night's Dream, Lopez set the piece underwater. 'Ms. Lopez drew on local talent, retaining the original choreography but giving it a new aquatic look, designed down to the last starfish by the Miami-born artist Michele Oka Donner' (Harss 2016). Lopez was Cuban-born but grew up in Miami until she left to study in New York at Balanchine's SAB, and one of her strengths has been to connect her company to its hometown. A board favorite to take over Miami City Ballet, her qualifications included fundraising, budgeting, and experience with the Balanchine roles already in the company's repertoire (Wakin 2012). In many ways, Lopez has achieved and exceeded those expectations, with ticket sales up and the $\$ 3$ million inherited debt nearly paid off. When asked about these successes, Lopez says, '[i]t all comes down to programming. You've got to get the dancers challenged and growing. The audience sees the dancers at the top of their game' (Harss 2016).

Lopez's success was not guaranteed four years ago, when she was left with a divided company and unsatisfied board. 'Those first weeks and months were not easy, but it seems her calm, steady energy - noticeable in conversation and in the studio - and her natural inclination to listen to those around her, helped the company ease into its new phase' (ibid.). If the recent New York tour is any indication, that 
new phase is a vibrant one. In developing dancers as the artistic director, she has proven an ally to women dancers like Simone Messmer. In developing the company, she has worked to connect it to the cultural roots of Miami. 'She is involved with the smallest details - even a pleat on a costume - but also teaches morning class two or three times a week, coaches dancers in rehearsals and hosts an informal performance series called Open Barre. She has preserved the company's family-like atmosphere, something that had been a part of Mr. Villella's original idea' (ibid.). In looking at her role as artistic director, Lourdes Lopez brings about change and success by approaching a very orthodox position in ways that challenge that orthodoxy. Where a figure like Misty Copeland changes what it means to be a principal dancer in a major ballet company, Lopez shifts the role of artistic director from the inside out using a female perspective.

\section{EMBRACING THE DIFFERENCES THAT WOMEN BRING: AN ANALYSIS OF WHAT THE STORIES OF COPELAND AND LOPEZ TELL US}

How can one describe the approach to leadership that both Copeland and Lopez use? Citing examples of empowering others to reach their full potential and including followers in the decision-making process are attributes associated with Transformational Leadership. Known also as Charismatic Leadership, this approach links leaders and followers (Northouse 2013). 'Transformational leadership is the process whereby a person engages with others and creates a connection that raises the level of motivation and morality in both the leader and the follower' (ibid., p. 186). It is clear that both Copeland and Lopez engage and create connections with others. James MacGregor Burns (1978, p. 4) states that 'the transforming leader looks for potential motives in followers, seeks to satisfy higher needs, engages the full person of the follower. The result of transforming leadership is a relationship of mutual stimulation and elevation.'

Lopez states that she is focused on being a 'fully realized human being' herself and she listens to her dancers. She promotes them to grow and be 'at the top of their game' (Lopez in Harss 2016). She knows that if her dancers are performing at their peaks, then she will benefit by having satisfaction in her leadership and audiences attending in higher numbers, ultimately solidifying her role as artistic director. Lastly, she has taken creative risks and has highlighted the works of female choreographers at performances of the Miami City Ballet.

Regarding Copeland, she is empowering others in multiple ways - through Project Plié, she is using her stature to promote ballet to children who are underrepresented in the art form. She is looking for potential in groups whom traditionally were not exposed and in turn promotes them in their accomplishments. Being given a chance to dance with a program like Project Plié, children may be motivated to give their very best and possibly become the next Misty Copeland. She gives them hope and, in return, is emboldened herself.

An interesting comparison to Lopez at Miami City Ballet is another recent appointment to the artistic director position. Ángel Corella, the former ABT principal dancer, took the helm of the Pennsylvania Ballet in 2014. In addition to making top-to-bottom changes to the company, he cites a revamped schedule of his own adaptations of classics like Le Corsaire alongside new work. 'There will also be world premieres of works by Brian Sanders, Nicolo Fonte, and the company's choreographer in residence, Matthew Neenan, as well as company premieres of works by David Dawson, Nacho Duato and 
Christopher Wheeldon' (Corella quoted in Cooper 2016). His roster of new works includes none by women choreographers.

In 2016 the company announced that, of the 43 dancers in the troupe, ' 17 would not return next season.' These cuts were made in the hopes of reshaping the company, which Corella believes will lead to higher ticket sales (Barone 2016). However, unlike Lopez, who has a much stronger grasp on her company's financial footing, Corella's moves are yet unproven. Moreover, the upheaval of dancers at Pennsylvania Ballet has not yet proven the company to be a stronger entity, as they have not enjoyed a New York tour with the success sustained by Lopez with Miami City Ballet. In a 2016 review of its New York tour, the Pennsylvania Ballet was described thus: 'it doesn't even look like a company: there are plenty of talented dancers, but with obviously different manners and styles. Will it become more cohesive in a few seasons' time?' (Macaulay 2016a). A woman as director might not have been given the opportunity to build through those seasons. Dance writer Garafola laments the ability of women with individual personalities to rise among the ranks of artistic directors, a position to which most women in ballet are shut out. 'I think there is a fundamental mistrust of a woman. She should be a muse. She should be a ballerina. She shouldn't be doing a man's job' (Garafola quoted in Basco 2015).

It is interesting to note that not all of Corella's past directing posts have been successful. 'Mr. Corella came to Philadelphia after the collapse of a different kind of quixotic quest: trying to establish a dance company in his native Spain' (Cooper 2016). When longtime Pennsylvania Ballet artistic director Roy Kaiser stepped down, Corella began his tenure by dismissing most of the company's top artistic staff, replacing them with his own hires. This kind of top-down control of ballet companies is not unfamiliar among the ranks of male artistic directors. And again, this style of hierarchical leadership is favored by men (Eagly and Johannesen-Schmidt 2001).

At NYCB, 'Mr. Martin's controlling personality has been a factor in alienating some onetime colleagues and dismissing others, most famously, Suzanne Farrell [Balanchine's favorite muse]' (Rockwell 2006). Martins was quoted as saying both that he came to NYCB for Balanchine and that he was not interested in his partners - his most famous being Suzanne Farrell - and has been criticized by The New Yorker dance critic Arlene Croce for not bringing in former dancers like Farrell, Allegra Kent, Melissa Hayden, Violette Verdy, and Patricia McBride, among others, to coach his current dancers in the roles they originated and were taught by Mr Balanchine himself (Sulcas 2013). Despite many qualified women with the same or, some would argue, better qualifications, the role of artistic director continues to go to men. Rachel Moore, former executive director at $\mathrm{ABT}$ and a former dancer, explains that 'the men are able to get the more solid jobs, for a variety of reasons. I think that it's still a man's world and for many places the male candidate is going to get chosen over the female candidate' (Basco 2015). Reasons for this, in Moore's view, include a history of boards being more comfortable with males, which are seen as more credible than females.

\section{SOCIETAL GENDER NORMS AND LEADERSHIP}

While understanding the world of classical ballet in terms of leadership and gender using a microscopic lens is interesting, it is also helpful to have a macro view of the subject. Researcher Alice Eagly and others have written much about gender norms and leadership. She highlights role congruity and how one's gender affects his or her perceived leadership effectiveness. Eagly and Karau state that women are 
known to be more 'communal' or having a 'primary concern with the welfare of other people - for example, affectionate, helpful, kind, sympathetic, interpersonally sensitive, nurturant and gentle' (Eagly and Karau 2002, p. 574). This notion is contrasted with being 'agentic,' a gender role ascribed more often to men. This term describes a role that has 'primarily an assertive, controlling, and a confident tendency - for example, aggressive, ambitious, dominant, forceful, independent, self-sufficient, self-confident, and prone to act as a leader' (ibid., p. 574). Clearly Balanchine fit well with a male gender role that was complementary to his leadership style. It would be interesting to know if today's female choreographers ascribe to the hierarchical style that Balanchine used or if they use a more feminine style that Eagly highlights.

Eagly and Karau go on to state that many people perceive successful leaders as having more agentic qualities. These qualities are described as 'competitive, self-confident, objective, aggressive, ambitious, and able to lead' (ibid., p. 575). And it should be noted that these attributes fit well as descriptors of a ballet dancer. One can easily see that men are in alignment with their agentic gender role when they act as leaders. However, when women use the same agentic strategies, they are often seen as not being feminine and not acting according to their gender roles. Women in ballet are nothing if not feminine in their movements and risk a great deal if they break with the historic views of this behavior. Hence, women face a 'double bind' while trying to be successful leaders because women risk retribution by not acting according to their socially constructed gender roles (Rhode 2003, p. 8). Put another way, women have difficulty being seen as competent leaders while also being perceived as appropriately nurturing or feminine. Specifically, in ballet, could it be that the ethereal dancers are deemed 'not aggressive enough' to lead?

While women may run ballet schools and become ballet company administrators and directors, they are rarely, if ever, invited to the choreographic high table. They are permitted responsibility, in other words, but not creative power. The consequence in recent years has been a succession of works, some forgettable, some memorably fine, but all bearing a recognizably male creative stamp. (Jennings 2013)

Why are women in ballet companies overlooked as leaders? According to Emily Coates (2014), '[w]omen tend not to be cultivated as leaders. The very definitions of "director" and "ballerina" sit in uneasy conflict.' Though the ballerina's image has become synonymous with the art itself, it is an image that has also been fraught with contradictions. As the aristocracy in Europe was replaced with an age in which commerce and democracy became increasingly the sources of power, the way in which the ballerina was considered also changed.

She went from being an amateur of noble birth to a professional of often humble origins, a creature of the marketplace subject to the whims and tastes of a paying audience. By the twentieth century, when ballet became established as an art form, the ballerina had become an object of both idealization and scorn in popular culture. (Kelly 2012, p. 3)

Part of this process happened by means of the proscenium stage, which is often described as giving the audience a window through which to watch the action upon the stage. It is within this window that the bodies of the performers are thus emphasized, and in the case of the ballerinas, this means a particular feminine form on display. That display became orchestrated by the tastes and whims of the artistic director, often a male, further skewing the representation towards showcasing the ballet dancer as an idealized and sexualized form. Balletomanes, or highly invested and typically male fans, attended performances encouraged to imagine not only what was presented on the stage, but what 
those same performing female bodies might do behind closed doors. Famously, the Paris Opera's dancers often courted lovers from among these balletomanes. 'Ballerinas had a number of incentives for moonlighting as courtesans: female dancers were generally paid less than their male counterparts, and yet they were responsible for living up to the standards set by the Opera's public image' (ibid., p. 17).

The opera and ballet were mainstays of French cultural life, and as depicted in the works of Edgar Degas, the ballet dancer evoked a world often cloaked in mystery, since access to the dancers offstage was typically restricted except for wealthy patrons. 'From one perspective, the ballerina is a subservient supplier of delights to male audiences and patrons, a concubine or a prostitute. An opposing point of view sees her as an artist of the loftiest cultural ideals and the image of femininity itself' (ibid., pp. 2-3). Figuratively balancing between these two images of the ballet dancer would result in literally balancing on one's toes.

\section{CONCLUSION}

Women have different lived experiences than men and with these experiences come different and often creative perspectives, and so too have been their leadership roles. Focusing on the composition of a ballet company and the benefits between and among the dancers, there is no doubt that, like Lourdes Lopez, Misty Copeland's lived experiences have created a more heterogeneous team at ABT. Not only because Copeland is a woman, but because of her non-white heritage. Beyond her 'team' at $\mathrm{ABT}$, she has broadened the perspective of dancers and patrons alike in creative and new ways. By her very introduction into the art form - through the Boys and Girls Club - she brings a different perspective on how one goes about auditioning for a company. And her heterogeneity has improved the art form.

It has long been known that heterogeneous groups outperform homogeneous groups. Hoffman and Maier (1961, p. 405) noted 'that heterogeneous groups are relatively superior to homogeneous groups in problem solving ability.' Leaders are often called upon to creatively solve problems. Leaders are also expected to have vision. Perhaps the difference that Copeland brings has influenced the thinking on creating Project Plié and who may become a principal dancer in a major ballet company. While Copeland is still actively dancing, she may find herself in roles like artistic director, similar to Lourdes Lopez, after she retires from performing.

A recent ABT retirement, principal dancer Julie Kent, was recently named artistic director at Washington Ballet. 'Kent, 46, will oversee all aspects of the Washington Ballet organization, including its 21-member company and trainee programs; its training arm, the Washington School of Ballet, with more than 1,000 students; and its community engagement activities, such as the satellite program in Anacostia and offerings in the District's public schools' (Kaufman 2016). Washington Ballet Board Chair Sylvia A. de Leon praised Kent's 'vision, energy and connection to the dancers' (ibid.). As Julie Kent retires and moves into the ranks of company direction, Misty Copeland continues at ABT, dancing many of Kent's former roles.

Copeland, unlike many other principal dancers in major ballet companies, has also expanded the reach of a ballerina, from a dainty figure on the stage to a competitive athlete who will 'win' in her sport. This athleticism is a new look for a dancer. Demonstrating strong and tediously toned muscles lends a different view of a woman dancer: one of power and leadership, not an ethereal sylph. Misty Copeland has expanded the ballerina's role in very innovative ways. 
Second, research shows that women value connections and tend to appreciate being in the middle of groups (Helgesen 1995, p. 46; Gerzema and D'Antonio 2013, p. 21). According to Helgesen (1995, p. 233), 'female values of inclusion and connection are emerging as valuable leadership qualities.' In contrast to Balanchine's ideal woman for the ballet, the connection that Copeland has with her audiences and children in Project Plié has begun to change the hierarchical structure. No longer is there only one type or 'look' of dancer that is allowed to progress through the ranks. She is leading the way for a more diverse group of dancers to be welcomed on the stage by colleagues and audiences alike.

In turn, people who choose to attend performances where Misty Copeland is one of the lead performers tend to reflect a broader assortment of backgrounds than those audiences where she does not perform. So not only does the inclusivity affect the team of dancers, it is also affecting the audience. The ripple effect of a diverse organization is farther reaching than within the doors of a specific company. Clearly Misty Copeland has inspired scores of young African American children to consider ballet as a hobby or as a profession.

Third, one could argue that the benefits of Lucia Chase as artistic director at American Ballet Theater and as a primary benefactor helped to develop it into the company it is today. Chase, who became artistic director in 1945, donated a large part of her personal fortune, much of which was left to her after the death of her husband, into ABT. These contributions occurred while a dancer in the company, as well as when she was artistic director.

In addition, as more diverse audiences watch performances by Misty Copeland, ABT will generate patrons and participants from segments of the population that, up until now, were virtually unwelcome at such shows. Presumably, the additional audience members will enhance the ticket sales and financial benefits to ABT. Likewise Lourdes Lopez, using her transformational style, is not only making the Miami City Ballet solvent and increasing ticket sales, but also adding a level of creativity that hasn't previously been seen.

It has been slow, but leadership is evolving in the world of classical ballet. From those who choreograph, direct, perform, and watch ballet, the face is definitely changing. Using the first African American principal dancer, Misty Copeland, as an example, it is clear that the tide is shifting. While she may be at the top of the hierarchy in its current structure, she is breaking down the barriers as to who can be in those roles at the highest level. Misty Copeland is definitely expanding the circle for those who may be a leader at $\mathrm{ABT}$ and in other companies. She has broken too many barriers to count and has had an impact on young people learning the craft like no other. Most significantly, helping to launch the Project Plié initiative she ensures socioeconomic and racial diversity in ballet training. Moreover, Project Plié represents the kind of leadership that women ballet dancers and former dancers can explore during and after their performing careers. While Misty Copeland is neither a choreographer nor artistic director, she has led the art of ballet in a new direction. With recent appointments like Julie Kent as artistic director of Washington Ballet, as well as the ongoing tenure of Lourdes Lopez at Miami City Ballet, there's hope that the artistic direction of ballet companies will continue to look to women for their leadership.

As women dancers approach retirement from performing, efforts need to be made to offer the kind of leadership and other kinds of training to ensure they have ongoing roles in the art form. ABT again has led the effort with the creation of the ABT National Training Curriculum. Dancers and alumni of ABT may take the certified training courses free of charge, giving them additional credentials for teaching. Many former ABT dancers find teaching opportunities at ABT's Jacqueline Kennedy 
Onassis School, the company's official school, while others find teaching opportunities elsewhere. Though this represents a significant opportunity for dancers, additional efforts along these lines should exist to train dancers and former dancers for roles in administration and artistic leadership in companies. Leadership institutes, training women for future roles as artistic directors or choreographers using the National Training Curriculum model, would be one way to help more women dancers achieve leadership positions. It is just one of many potential avenues to fast-track the slow-changing face of women in leadership positions in American ballet companies.

\section{REFERENCES}

Barone, Joshua (2016), 'Angel Corella of Pennsylvania Ballet upends troupe, reflecting new vision,' The New York Times, April 26, available at: http://www.nytimes.com/2016/04/27/ arts/dance/angel-corella-of-pennsylvania-ballet-upends-troupe-reflecting-new-vision.html?_r= (accessed May 4, 2016).

Basco, Sharon (2015), 'Where are the women in ballet?' ARTery Magazine, September 18, available at: http://artery.wbur.org/2015/09/18/women-in-ballet (accessed May 6, 2016).

Burns, James MacGregor (1978), Leadership, New York: Harper \& Row.

Carli, Linda L. and Alice H. Eagly (2001), 'Gender, hierarchy, and leadership: an introduction,' Journal of Social Issues, 57(4), 629-636.

Cartwright, Dorwin and Alvin F. Zander (1968), Group Dynamics: Research and Theory, New York: Harper \& Row.

Catalyst (2016), Women CEOs of the S\&P 500, New York: Catalyst, February 1.

Catton, Pia (2015), 'Misty Copeland take the stage in Swan Lake,' The Wall Street Journal, June 25.

Coates, Emily (2014), 'Spectral ballerinas: on a pedestal, written out of history,' Huffington Post, January 27.

Cooper, Michael (2016), 'This man is trying to reinvent the Pennsylvania Ballet,' The New York Times, March 17.

Copeland, Misty (2014), Life in Motion: An Unlikely Ballerina, New York: Touchstone.

Copley, Joseph (2014), personal communication, November 10.

Eagly, Alice H. and May G. Johannesen-Schmidt (2001), 'The leadership styles of women and men,' Journal of Social Issues, 57(4), 781-797.

Eagly, Alice H. and Stephen J. Karau (2002), 'Role congruity theory of prejudice toward female leaders,' Psychological Review, 109(3), 573-598.

French, John R. and Bertram Raven (1959 [1968]), 'The bases of social power,' in D. Cartwright and A. Zander (eds), Group Dynamics: Research and Theory, New York: Harper \& Row, pp. 259-269.

Furst, Stacie and Martha Reeves (2008), 'Queens of the hill: creative destruction and the emergence of executive leadership of women,' The Leadership Quarterly, 19, 372-384.

Gerzema, John and Michael D'Antonio (2013), The Athena Doctrine: How Women (and the Men Who Think Like Them) Will Rule the Future, San Francisco: Jossey-Bass.

Guillermo, Perez (2013), 'Through the glass ceiling: Lourdes Lopez,' Dance Magazine, 87(11), $32-33$.

Harss, Marina (2016), 'Miami City Ballet: feeling that warmth and attack,' The New York Times, April 8.

Haslam, S. Alexander and Michelle K. Ryan (2008), 'The road to the glass cliff: differences in the perceived suitability of men and women for leadership positions in succeeding and failing organizations,' The Leadership Quarterly, 19, 530-546.

Helgesen, Sally (1995), The Female Advantage: Women's Ways of Leadership, Washington, DC: Doubleday.

Hoffman, L. Richard and Norman Maier (1961), 'Quality and acceptance of problem solutions by members of homogeneous and heterogeneous groups,' Journal of Abnormal and Social Psychology, 62(2), 401-407. 
Homans, Jennifer (2010), Apollo's Angels: A History of Ballet, New York: Random House.

James, Clive (2007), Cultural Amnesia: Necessary Memories from History and the Arts, New York: W.W. Norton.

Jennings, Luke (2013), 'Sexism in dance: where are all the female choreographers?' The Guardian, April 28.

Kaufman, Sarah L. (2016), 'ABT star Julie Kent is Washington Ballet's new artistic director,' The Washington Post, March 7.

Kelly, Deirdre (2012), Ballerina: Sex, Scandal, and Suffering Behind the Symbol of Perfection, Vancouver, BC: Greystone Books.

Kirkland, Gelsey and Greg Lawrence (1986), Dancing on my Grave, New York: Doubleday.

Kourlas, Gia (2015), 'The reinvention of Simone Messmer,' Dance Magazine, December.

Macaulay, Alastair (2016a), 'Review: for Pennsylvania Ballet, transitions onstage and off,' The New York Times, March 30.

Macaulay, Alastair (2016b), 'Review: Miami City Ballet, a troupe at home outside its turf,' The New York Times, April 14.

Macaulay, Alastair (2016c), 'Miami City Ballet, dancing Balanchine, raise the bar in New York,' The New York Times, April 17.

Maxfield, Sylvia, Mary Shapiro, Vipin Gupta, and Susan Hass (2010), 'Gender and risk: women, risk taking and risk aversion,' Gender in Management: An International Journal, 25(7), 586-604.

Northouse, Peter (2013), Leadership: Theory and Practice, Sixth Edition, Thousand Oaks, CA: Sage.

Rhode, Deborah L. (2003), 'The difference "difference” makes,' in Deborah L. Rhode (ed.), The Difference 'Difference' Makes: Women and Leadership, Stanford, CA: Stanford University Press, pp. 3-50.

Rockwell, John (2006), 'A controversial season for City Ballet and Peter Martins,' The New York Times, April 23.

Seiwert, Amy (2014), personal communication, November 10.

Sulcas, Roslyn (2013), 'City Ballet's leader, 30 years in,' The New York Times, April 19.

Under Armor (2014), 'Misty Copeland - I WILL WHAT I WANT,' online video clip, YouTube, July 30 .

Wakin, Daniel J. (2012), 'Balanchine disciple chosen to lead Miami City Ballet,' The New York Times, April 3.

West, Martha Ullman (2010), 'George Balanchine, ballet revolutionary,' Dance Magazine, 84(7), 74.

Women in the US Congress (2016), Center for American Women and Politics, Eagleton Institute of Politics, Rutgers University, available at: http://www.cawp.rutgers.edu/current-numbers (accessed June 1, 2016).

\section{FURTHER READING}

Choi, Sungjoo and Hal G. Rainey (2014), 'Organizational fairness and diversity management in public organizations: does fairness matter in managing diversity?' Review of Public Personnel Administration, 34(4), 307-331.

Cray, David, Loretta Ingliss, and Susan Freeman (2007), 'Managing the arts: leadership and decision making under dual rationalities,' Journal of Arts Management, Law, and Society, 36(4), 295-313.

Denhardt, Robert B. and Janet V. Denhardt (2006), The Dance of Leadership: The Art of Leading in Business, Government and Society, Armonk, NY and London: M.E. Sharpe.

Furher, Margaret (2012), 'Seen not heard,' Pointe, 13(6), available at: http://pointemagazine. com/inside-pt/issuesdecember-2012january-2013seen-not-heard/ (accessed June 25, 2015).

Helgesen, Sally (2005), The Web of Inclusion: Architecture for Building Great Organizations, Washington, DC: Doubleday. 
Herman, Robert D. and Associates (2005), The Jossey-Bass Handbook of Nonprofit Leadership and Management, San Francisco, CA: Jossey-Bass.

Higgs, Malcolm, Ulrich Plewnia, and Jorg Ploch (2005), 'Influence of team composition and task complexity on team performance,' Team Performance Management, 11(7/8), 227-250.

Reid, W. (2007), 'Institutionalized, mandated dual leadership in nonprofit arts organizations: one conceptualization of the phenomenon and its implications for organizational effectiveness,' Valencia, Spain: 9th International Conference on Arts and Cultural Management (AIMAC).

Reid, Wendy and Rekha Karambayya (2009), 'Impact of dual executive leadership dynamics in creative organizations,' Human Relations, 62(7), 1073-1112.

Temin, Christine (2009), Behind the Scenes at Boston Ballet, Gainesville, FL: University of Florida Press.

Tharp, Twyla (2003), The Creative Habit: Learn It and Use It For Life, New York, London, Toronto, and Sydney: Simon \& Schuster Paperbacks.

Thomas, Leigh (2014), 'I went from ballet dancer to CEO and this is what it taught me,' The Guardian, June 23. 